\title{
Dynamika zjawiska zamachów samobójczych wśród dzieci w Polsce w latach 2010-2020 w świetle policyjnych danych statystycznych
}

\section{Dynamics of the phenomenon of suicide among children in Poland in 2010-2020 in the light of statistical police data}

\begin{abstract}
ABSTRAKT: Niniejsze opracowanie poświęcono analizie danych statystycznych Komendy Głównej Policji za lata 2010-2020 dotyczących zamachów samobójczych popełnianych przez dzieci w Polsce. W opracowaniu posłużono się dwiema metodami badawczymi. Wiodącą była analiza danych statystycznych. Użyto również metody analizy literatury przedmiotu. Celem było przede wszystkim podjęcie próby charakterystyki dynamiki wspomnianego zjawiska. Rozważania oparto na analizie danych dotyczących grup wiekowych, powodu zamachów samobójczych w postaci problemów szkolnych oraz kategorii określanej jako „informacje o nauce/pracy - uczeń”. Dane te analizowano pod kątem liczby zamachów samobójczych niezakończonych zgonem oraz tych, w których do niego doszło.
\end{abstract}

SŁOWA KLUCZOWE: samobójstwa dzieci, statystyki policyjne, dynamika zjawiska

ABSTRACT: This study is devoted to the analysis of the statistical data of the National Police Headquarters for 2010-2020 regarding suicide attacks committed by children in Poland. Two research methods were used in the study. The leading method was the analysis of statistical data. The method of analyzing selected literature on the subject was also used. The aim was, above all, to attempt to characterize the dynamics of the phenomenon of suicide attacks among children in Poland in 2010-2020 in the light of police statistical data. The considerations were based on the analysis of data on age groups, the reasons for the suicide attacks in the form of school problems and the category referred to as "information about learning / work - student". These data were analyzed in terms of the number of non-fatal suicide attacks and those in which they occurred.

KEYWORDS: child suicides, police statistics, dynamics of the phenomenon 


\section{Wprowadzenie}

Targnięcie się na własne życie godzi w najważniejsze i najcenniejsze dobro, które posiada człowiek. Zjawisko samobójstwa dotyka ludzi niezależnie od ich statusu majątkowego, płci czy wykształcenia. Również wiek osób, które chcą się pozbawić życia, nie jest określony w ścisłym przedziale. Jednakże nie ulega wątpliwości, że im niższy jest to wiek (tj. mamy do czynienia z próbą samobójczą czy samobójstwem dziecka), sytuacja taka szokuje bardziej i staje się przyczynkiem do dyskusji - zarówno tych naukowych, jak i medialnych.

Niniejsze opracowanie poświęcono analizie danych statystycznych zamieszczonych na stronie internetowej Komendy Głównej Policji (KGP), dotyczących zamachów samobójczych oraz samobójstw dokonywanych przez dzieci w Polsce w latach 2010-2020. Przedstawienie oraz analiza tych danych umożliwiły podjęcie próby charakterystyki dynamiki tego zjawiska. W publikacji zwrócono również uwagę na 2020 r., który był specyficzny ze względu na sytuację sanitarno-epidemiologiczną panującą w Polsce i na świecie. Na skutek lockdownu dzieci rozpoczęły naukę zdalną, a tym samym musiały pozostać w domach, ucząc się przed komputerami, odseparowane od swoich rówieśników. W opracowaniu posłużono się dwiema metodami badawczymi. Wiodącą była analiza danych statystycznych. Użyto także metody analizy wybranej literatury przedmiotu.

\section{Kategorie policyjnych danych statystycznych dotyczących samobójstw, w tym samobójstw dzieci, i przykłady związanych z nimi trudności interpretacyjnych}

Dane dotyczące zamachów samobójczych, w tym tych zakończonych zgonem, zamieszczone są do publicznej wiadomości na stronie internetowej KGP' Znajdują się tam trzy zakładki z plikami w formacie pdf.

Pierwsza zakładka dotyczy danych najnowszych, tj. pochodzących $z$ lat 2017-2020². Druga - danych za lata 2013-20163. Trzecia zaś zawiera statystyki $\mathrm{z}$ lat $1999-2012^{4}$. Uzasadnienie takowego podziału, jak wskazano na stronie internetowej KGP, „wynika z faktu, że do 2012 r. dane dotyczące samobójstw gromadzone i generowane były na podstawie druku - »Zgłoszenie zamachu

${ }^{1}$ https://statystyka.policja.pl/st/wybrane-statystyki/zamachy-samobojcze [dostęp: 11.05.2021].

${ }^{2}$ https://statystyka.policja.pl/st/wybrane-statystyki/zamachy-samobojcze/63803,Zamachy-samobojcze-od-2017-roku.html [dostęp: 11.05.2021].

3 https://statystyka.policja.pl/st/wybrane-statystyki/zamachy-samobojcze/122324,Zamachy-samobojcze-od-2013-do-2016.html [dostęp: 11.05.2021].

${ }^{4}$ https://statystyka.policja.pl/st/wybrane-statystyki/zamachy-samobojcze/122325,Zamachy-samobojcze-od-1999-do-2012.html [dostęp: 11.05.2021]. 
samobójczego«, który wprowadzany był do systemu PSSP Temida po przeprowadzeniu i zakończeniu postępowania sprawdzającego, w trybie art. $308 \mathrm{kpk}$ lub postępowania przygotowawczego. Od 2013 r. zmienił się sposób gromadzenia i generowania danych statystycznych dotyczących zamachów samobójczych. Obecnie dane wprowadzane są do KSIP za pośrednictwem formularza "Rejestracja zgłoszenia zamachu samobójczego« bezpośrednio po wydarzeniu

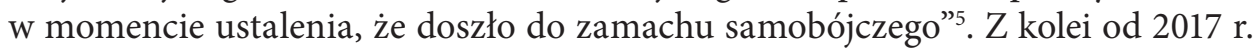
ponownie zmieniony został formularz oraz rozszerzono zakres gromadzonych danych ${ }^{6}$. Używane w dalszej części rozważań sformułowanie „zamach samobójczy" jest zatem nazewnictwem zaczerpniętym wprost ze statystyk policyjnych. Nie zostało ono jednak przez ich twórcę w żaden sposób zdefiniowane.

Statystyki KGP dotyczące zamachów samobójczych są bardzo szerokie. Zawarte w nich dane podzielono na wiele kategorii. Podstawowy jest podział na zamachy samobójcze zakończone zgonem oraz te, w których do niego nie doszło. Ze względu na wagę zjawiska istotne jest porównanie liczby zamachów samobójczych dzieci, w których doszło do śmierci, z tymi, w których dziecko jednak przeżyło.

W obrębie wskazanych grup dane podzielone zostały m.in. na kategorie takie jak: wiek, dzień tygodnia (w którym doszło do zamachu), sposób popełnienia, powód, stan cywilny, informacja o nauce/pracy, wykształcenie.

$\mathrm{Na}$ potrzeby niniejszego opracowania analizie poddano dane dotyczące wieku, powodu popełnienia zamachu określanego jako „problemy szkolne” oraz informacji o pracy lub nauce (kategoria „uczeń”). Są to kategorie, które stricte można odnieść do dzieci.

Pozostałe dane statystyczne dotyczące sposobu czy innych powodów popełnienia zamachu samobójczego mogą odnosić się również do dorosłych samobójców. Niestety, w statystykach KGP poszczególne przyczyny samobójstw czy sposoby dokonania tego czynu zostały podane bez wyszczególnienia wieku samobójców. Stanowi to istotny problem w interpretacji dynamiki tego zjawiska wśród dzieci. Bez wątpienia trudności w szkole nie są jedynym czynnikiem mogącym popchnąć dziecko do tak tragicznej w skutkach decyzji, jaką jest targnięcie się na swoje życie. Problemy rodzinne, zdrowotne lub niechciana ciąża także mogą być tego przyczyną. Bez wyszczególnienia jednak kategorii wiekowych nie ma możliwości interpretacji tych danych jedynie w kontekście samobójstw dzieci.

Już na wstępie można więc zauważyć, że obraz wyłaniający się z analizy statystyk nie będzie pełny z powodu braku powiązania przedziałów wiekowych z innymi kategoriami tych danych. Najbardziej pożądana byłaby bowiem sy-

${ }^{5}$ https://statystyka.policja.pl/st/wybrane-statystyki/zamachy-samobojcze [dostęp: 11.05.2021].

${ }^{6}$ https://statystyka.policja.pl/st/wybrane-statystyki/zamachy-samobojcze [dostęp: 11.05.2021]. 
tuacja, w której dane odnoszące się do poszczególnych przyczyn zamachów samobójczych przedstawione zostałyby z uwzględnieniem wieku samobójców. Już chociażby wyodrębnienie dwóch grup:

1) samobójcy do 18. roku życia,

2) samobójcy po 18. roku życia, pozwoliłoby na wskazanie, które przyczyny samobójstw w policyjnej statystyce dotyczą dzieci i młodzieży, a które osób dorosłych. Jeszcze lepszym rozwiązaniem byłoby podzielenie tychże danych na więcej przedziałów wiekowych, np. $\mathrm{z}$ uwzględnieniem etapów edukacji (tj. dzieci w wieku od 0 do 6 lat, dzieci w wieku odpowiadającym nauczaniu w szkole podstawowej/średniej itd.).

Warto też $\mathrm{w}$ tym miejscu wspomnieć, że statystyki policyjne na pewno nie ujmują wszystkich przypadków zamachów samobójczych, które rzeczywiście w badanym przedziale czasowym się wydarzyły. Możemy tu mieć do czynienia ze zjawiskiem tzw. ciemnej liczby. Przykładem może być choćby przypadek, w którym rodzic znalazłby swoje dziecko próbujące dokonać samobójstwo przez powieszenie i mu w tym przeszkodził, nie dopuszczając do poważnych następstw tego zdarzenia. Jeżeli nikt nie zgłosiłby sytuacji policji lub innym organom, dziecko nie trafiłoby do szpitala, a na jego ciele nie byłoby widać obrażeń sugerujących, że mogła wydarzyć się próba samobójcza - wtedy taka sytuacja nie trafiłaby przecież do policyjnej statystyki. Pomimo tego nie oznacza to jednak, że owo zdarzenie nie miało miejsca. Przyczyną niezgłoszenia takiego zajścia nie musi być tylko brak obrażeń u dziecka. Rodzic czy opiekun może się także wstydzić tego, co się zdarzyło, i to spowoduje, że informacja o próbie samobójczej nie trafi do statystyki.

Jako kolejny przykład można wskazać rzucenie się pod samochód, które przez organy ścigania zakwalifikowane może być jako wypadek komunikacyjny. W większości sytuacji przecież szybkie i niespodziewane wtargnięcie pieszego czy rowerzysty na jezdnię nie świadczy o chęci popełnienia samobójstwa, lecz bywa skutkiem zamyślenia, nieuwagi, nierespektowania zasad ruchu drogowego.

Należy także podkreślić, że samobójstwo (niezależnie od tego, czy jest zakończone zgonem, czy też nie) nie stanowi przestępstwa na gruncie polskiego porządku prawnego. Kodeks karny z 1997 r. w art. 151 penalizuje jedynie przestępstwo pomocy w samobójstwie lub namowy do niego, czyli tzw. doprowadzenia do samobójstwa ${ }^{7}$. Policję interesuje również ewentualny udział osób trzecich $\mathrm{w}$ upozorowaniu samobójstwa celem ukrycia popełnienia przestępstwa zabójstwa (z art. 148 k.k.) lub nieumyślnego spowodowania śmierci (z art. 155 k.k.). Jeżeli jednak okazuje się, że żadne $\mathrm{z}$ wymienionych przestępstw nie miało miej-

7 Ustawa z dnia 6 czerwca 1997 r. - Kodeks karny (Dz.U. z 2021 r., poz. 1023); art. 151 k.k. stanowi, że „kto namową lub przez udzielenie pomocy doprowadza człowieka do targnięcia się na własne życie, podlega karze pozbawienia wolności od 3 miesięcy do lat 5”. 
sca, wtedy policja jedynie odnotowuje zdarzenie i nie prowadzi postępowania w sprawie. Stąd też wynikać może fakt, że dane te będą niepełne ${ }^{8}$.

\section{Zamachy samobójcze dzieci z uwzględnieniem ich wieku}

W pierwszej kolejności warto dokonać porównania ogólnej liczby zamachów samobójczych w Polsce w latach 2010-2020 z liczbą prób samobójczych dzieci w wieku 0-18 lat, z podziałem na zamachy samobójcze zakończone oraz niezakończone zgonem. Porównanie to przedstawiono w tabeli 1. Przyjęcie granicy 18. roku życia podyktowane jest faktem, że w polskim ustawodawstwie osiągnięcie pełnoletności (czyli ukończenie 18 lat) oznacza formalne stanie się osobą dorosłą. Do tego roku istnieje również obowiązek nauki ${ }^{9}$.

Tabela 1. Porównanie ogólnej liczby zamachów samobójczych w Polsce w latach 2010-2020 z liczbą prób samobójczych dzieci w wieku 0-18 lat, z podziałem na zamachy samobójcze zakończone oraz niezakończone zgonem

\begin{tabular}{|c|c|c|c|c|}
\hline \multirow{2}{*}{ Rok } & \multicolumn{4}{|c|}{ Liczba zamachów samobójczych w Polsce } \\
\cline { 2 - 5 } & \multicolumn{2}{|c|}{ ogółem } & \multicolumn{2}{c|}{ dzieci (0-18 lat) } \\
\cline { 2 - 5 } & bez zgonu & zgon & bez zgonu & zgon \\
\hline 2010 & 5456 & 4087 & 273 & 123 \\
\hline 2011 & 5124 & 3839 & 248 & 114 \\
\hline 2012 & 5791 & 4177 & 291 & 139 \\
\hline 2013 & 8575 & 6101 & 357 & 148 \\
\hline 2014 & 10207 & 6165 & 442 & 127 \\
\hline 2015 & 9973 & 5688 & 481 & 119 \\
\hline 2016 & 9861 & 5405 & 475 & 116 \\
\hline 2017 & 11139 & 5276 & 730 & 97 \\
\hline 2018 & 11167 & 5182 & 769 & 98 \\
\hline 2019 & 11961 & 5255 & 951 & 107 \\
\hline 2020 & 12013 & 5165 & 843 & \\
\hline
\end{tabular}

Źródło: Opracowanie własne na podstawie danych statystycznych KGP.

8 D. Rząsa, Samobójstwa nastolatków - dlaczego oficjalne statystyki pokazuja tylko część prawdy, https://sledztwopisma.pl/sledztwo-w-liczbach/samobojstwa-nastolatkow-dlaczegooficjalne-statystyki-pokazuja-tylko-czesc-prawdy/ [dostęp: 1.09.2021].

9 Art. 35 ustawy z dnia 14 grudnia 2016 r. - Prawo oświatowe (Dz.U. z 2021 r., poz. 1082): „1. Nauka jest obowiązkowa do ukończenia 18. roku życia.

2. Obowiązek szkolny dziecka rozpoczyna się z początkiem roku szkolnego w roku kalendarzowym, w którym dziecko kończy 7 lat, oraz trwa do ukończenia szkoły podstawowej, nie dłużej jednak niż do ukończenia 18. roku życia”. 
Należy zauważyć, że ogólna liczba zamachów samobójczych w Polsce w latach 2010-2020 odnotowywana była $\mathrm{w}$ tysiącach. W przypadku prób samobójczych niezakończonych zgonem liczba ta $\mathrm{w}$ ciągu dekady wzrosła $\mathrm{z}$ poziomu ponad 5 tys. przypadków rocznie do poziomu ponad 12 tys. przypadków. Oznacza to, że wzrosła ona ponad dwukrotnie. Mniej odnotowano zaś zamachów samobójczych zakończonych zgonem. Najwięcej ich przypadło na 2014 r. tj. 6165 przypadków, a najmniej na 2011 r. - niecałe 4 tys. przypadków. Warto jednakże podkreślić, że nadal są to wartości znaczne $\mathrm{z}$ uwagi na fakt, że oznaczają utratę życia przez człowieka. Nie ulega wątpliwości, że wzrastająca przez lata liczba samobójstw wynika chociażby z ciągłego rozwoju społeczeństwa (na różnych płaszczyznach) i stale powiększających się jego potrzeb, które niezaspokajane (np. z powodu braku środków finansowych) mogą prowadzić do frustracji, utraty sensu egzystencji, a w konsekwencji nawet do próby targnięcia się na swoje życie.

Pośród dzieci również wyższe wartości odnotowywane były w przypadku zamachów samobójczych niezakończonych zgonem. Samobójstw, które skutkowały utratą życia, rejestrowano mniej. W wypadku dzieci różnice te rzeczywiście były znaczne - zwłaszcza w latach 2017-2020. Wyjaśniając ten fakt, można by twierdzić, że sytuacja taka mogła zaistnieć na skutek niedostatecznej wiedzy dzieci o tym, w jaki sposób można odebrać sobie życie. Stanowisko to wydaje się jednak w dzisiejszych czasach nieuzasadnione. W dobie Internetu i dostępu do różnorakich treści młody człowiek jest w stanie wyszukać informacje o skutecznych metodach popełnienia samobójstwa, np. poprzez użycie trucizny. Ponadto w Sieci powstają specjalne fora, witryny oraz strony poświęcone tematyce samobójstw. Określić je można rodzajem swoistych „poradników” dla osób pragnących odebrać sobie życie. Stanowią ogólnodostępną bazę wiedzy na ten temat ${ }^{10}$. Również dostęp do niebezpiecznych substancji w czasach zakupów online jest dużo prostszy niż chociażby dekadę temu.

Bardziej trafne wydaje się stwierdzenie, że odnotowana liczba zamachów samobójczych niezakończonych zgonem była większa niż tych, gdzie do zgonu doszło, ponieważ swoim zachowaniem (zamachem na życie) dziecko nie chce doprowadzić do nieodwracalnego skutku, a bardziej ma na celu np. zwrócenie na siebie i swoje problemy uwagi rodziców czy opiekunów. Często zabiegani dorośli nie są w stanie zauważyć, że coś niepokojącego dzieje się z ich dzieckiem. Dopiero podjęcie przez nie próby samobójczej sprawia, że dorosły zwraca na dziecko uwagę i próbuje dociec, co było przyczyną takiego zachowania.

Zamachy samobójcze dzieci w ostatniej dekadzie niemal rokrocznie liczone były w setkach przypadków. Udział tych prób w ogólnej liczbie zamachów samo-

10 M. Rzadkowska, Zachowania samobójcze wśród dzieci i młodzieży - charakterystyka ryzyka i profilaktyka, „Studia Prawnicze. Rozprawy i Materiały” 2016, nr 1 (18), s. 166; zob. też: P. Drzewiecki, Samobójstwa nastolatków w Internecie w perspektywie pedagogiki mediów, „Kultura - Media - Teologia" 2011, nr 2, s. 61-72. 
bójczych w Polsce wydaje się zatem zauważalny. W przypadku niezakończonych zgonem prób odebrania sobie życia przez dzieci w ciągu dekady liczba ta wzrosła z poziomu niemal 300 przypadków (lata 2010-2012) do 951 w 2019 r. Oznacza to, że uległa ona niemal trzykrotnemu wzrostowi. Z kolei zamachy samobójcze dzieci skutkujące zgonem w latach 2010-2020 nie przekroczyły 150 przypadków rocznie. Najwięcej takich sytuacji odnotowano w 2013 r. (148 przypadków).

Bardziej szczegółowo liczbę zamachów samobójczych dzieci z uwzględnieniem wybranych grup wiekowych w poszczególnych latach przedstawiono w tabeli 2 .

Tabela 2. Liczba zamachów samobójczych dzieci w Polsce w latach 2010-2020 z uwzględnieniem wybranych grup wiekowych

\begin{tabular}{|c|c|c|c|c|c|c|}
\hline \multirow{2}{*}{ Rok } & \multicolumn{7}{|c|}{ Wybrane grupy wiekowe } & \multicolumn{2}{c|}{$13-18$ lat } \\
\cline { 2 - 7 } & \multicolumn{2}{|c|}{$0-6$ lat } & \multicolumn{2}{c|}{$7-12$ lat } & bez zgonu & zgon \\
\cline { 2 - 7 } & bez zgonu & zgon & bez zgonu & zgon & 267 & 119 \\
\hline 2010 & 0 & 0 & 6 & 3 & 243 & 111 \\
\hline 2011 & 0 & 0 & 5 & 1 & 286 & 138 \\
\hline 2013 & 0 & 0 & 5 & 4 & 348 & 144 \\
\hline 2014 & 0 & 0 & 9 & 3 & 428 & 124 \\
\hline 2015 & 0 & 0 & 14 & 5 & 469 & 114 \\
\hline 2016 & 0 & 0 & 9 & 2 & 466 & 101 \\
\hline 2017 & 0 & 0 & 28 & 1 & 702 & 115 \\
\hline 2018 & 0 & 0 & 23 & 5 & 746 & 92 \\
\hline 2019 & 0 & 0 & 46 & 4 & 905 & 94 \\
\hline 2020 & 0 & 0 & 29 & 1 & 814 & 106 \\
\hline
\end{tabular}

Źródło: Opracowanie własne na podstawie danych statystycznych KGP.

\section{Dzieci w wieku 0-6 lat}

Należy zauważyć, że w latach 2010-2020 w grupie wiekowej 0-6 lat nie odnotowano (według danych KGP) ani jednego przypadku próby targnięcia się na swoje życie. Oczywiście nie oznacza to, że wszystkie dzieci w Polsce w ciągu ostatnich 10 lat były wychowywane w poczuciu bezpieczeństwa oraz żyły w idealnych, kochających się rodzinach. Funkcjonują przecież w naszym kraju rodziny dysfunkcyjne - czy to na skutek uzależnień, które dotykają rodziców (np. alkoholizm), czy też jakiejkolwiek innej niewydolności wychowawczej. Jak wskazuje się w literaturze przedmiotu, mimo że dysfunkcjonalność rodziny podnosi ryzyko wystąpienia zachowań samobójczych, to czynnik ten nie jest decydujący, a problem „może dotyczyć młodzieży ze wszystkich środowisk i warstw 
społecznych"11. Cytowane słowa pochodzą co prawda z publikacji dotyczącej dzieci w wieku 14-18 lat, wydaje się jednak, że nic nie stoi na przeszkodzie, aby mogły być one uznane za trafne także w przypadku dzieci młodszych.

Brak odnotowanych przypadków zamachów samobójczych w kategorii wiekowej 0-6 lat sugerować może, że pomimo problemów rodzinnych, np. alkoholizmu jednego z rodziców, rodzic niepijący lub inni bliscy starają się zapewnić dziecku takie środowisko i atmosferę, aby nie odczuło ono „problemów dorosłych". Przede wszystkim jednak zwrócić należy uwagę na etap rozwoju tak małego dziecka.

Ta kategoria wiekowa jest to ten czas, z którego w dalszym życiu zachowuje się niewiele wspomnień. Wydaje się również, że jest to wiek, w którym dziecko nie jest świadome możliwości pozbawienia siebie życia. Jak twierdzi Brunon Hołyst, „w przypadku samobójstw popełnianych przez dzieci i młodzież, ich pełna świadomość podejmowanego czynu budzi wątpliwości ze względu na brak doświadczenia życiowego oraz rozumienia tego, co tak naprawdę oznacza podjęcie decyzji o tak drastycznym zakończeniu problemów, które ofiary napotkały na początku swojego życia"12. Z kolei Krystyna Kuberska-Przekwas wskazuje, że „dzieci nie mają poczucia własnej śmiertelności. Pojęcie śmierci rozwija się pod koniec dorastania, kiedy dziecko staje się zdolne, by intelektualnie przyswoić fizjologiczne, metafizyczne, a także biologiczne aspekty śmierci"13.

Ponadto, jest to też przedział wiekowy, w którym dziecko nie uczęszcza jeszcze do szkoły podstawowej, a tym samym potencjalne przyczyny samobójstw $\mathrm{w}$ postaci problemów związanych $\mathrm{z}$ przebywaniem $\mathrm{w}$ takim środowisku również nie mogą zaistnieć. Oczywiście, dziecko może uczęszczać w tym czasie do przedszkola/żłobka. Nie wydaje się jednak, by mogło napotkać tam takie problemy, które spowodowałyby świadome podjęcie decyzji o targnięciu się na swoje życie.

Warto zatem zauważyć, że na brak odnotowanych zamachów samobójczych w tym przedziale wiekowym wpływ ma stan rozwoju psychicznego dziecka wynikający z jego wieku.

Wydawać by się mogło, że ze względu na brak odnotowywanych w tej kategorii wiekowej przypadków nie ma potrzeby wspominania i szerszego analizowania kwestii zamachów samobójczych dzieci w wieku 0-6 lat. Moim zdaniem warto jednak te dane przytoczyć i choćby w kilku zdaniach wskazać, że jest to

${ }_{11}$ M. Makara-Studzińska, Przyczyny prób samobójczych u młodzieży w wieku 14-18 lat, „Psychiatria” 2013, t. 10, nr 2, s. 76; M. Rzadkowska, Zachowania samobójcze..., s. 165.

12 B. Hołyst, Suicydologia, LexisNexis, Warszawa 2012, cyt. za: A. Bąbik, D. Olejniczak, Uwarunkowania i profilaktyka samobójstw wśród dzieci i młodzieży w Polsce, „Dziecko Krzywdzone. Teoria, badania, praktyka" 2014, vol. 13, no. 2, s. 100.

${ }_{13}$ K. Kuberska-Przekwas, Samobójstwa dzieci i młodzieży jako choroba społeczna, „Warmińsko-Mazurski Kwartalnik Naukowy, Nauki Społeczne” 2014, nr 1, s. 56. 
pozytywna informacja. Poza tym z uwagi na naukowy charakter tego opracowania pominięcie tej kategorii wiekowej było nieuzasadnione.

\section{Dzieci w wieku 7-12 lat}

Kolejną kategorię wiekową stanowią dzieci $\mathrm{w}$ wieku od 7 do 12 lat. Jest to czas, w którym dziecko uczy się w szkole podstawowej, coraz intensywniej poznaje świat, kształtuje swoje kontakty z rówieśnikami. Wchodzi także w okres dojrzewania. Należy zatem zauważyć, że w porównaniu z poprzednim przedziałem wiekowym tutaj młody człowiek staje $\mathrm{w}$ obliczu znacznie większej liczby potencjalnie problematycznych sytuacji. Mowa tu np. o kłopotach $\mathrm{z}$ nauką, problemach $\mathrm{w}$ relacjach rówieśniczych (zwłaszcza, gdy dziecko czymś różni się od rówieśników) czy też zmianach w nastroju lub wyglądzie, które są następstwem wejścia $\mathrm{w}$ okres dojrzewania ${ }^{14}$.

W tej kategorii wiekowej w ciągu ostatniej dekady niestety odnotowywane już były zamachy samobójcze. W przypadku prób samobójczych niezakończonych zgonem do 2013 r. ich liczba nie przekroczyła 10 osób rocznie. W latach 2011-2012 odnotowano ich najmniej, tj. po 5 takich przypadków na rok. W 2014 r. liczba ta wzrosła do 14, jednakże w kolejnych latach - do 2016 r. wykazywała tendencję spadkową. Spadła ona nawet do poziomu poniżej $10 \mathrm{za}-$ machów samobójczych (w 2016 r.). Znaczny wzrost tej liczby nastąpił w 2017 r. (ponadtrzykrotny). W $2018 \mathrm{r}$. liczba ta utrzymywała się nadal na poziomie ponad 20 zamachów samobójczych. Najwięcej prób samobójczych niezakończonych zgonem w kategorii wiekowej 7-12 lat przypadło na 2019 r. - 46 przypadków. W porównaniu z $2018 \mathrm{r}$. był to dwukrotny wzrost tej liczby.

Warto jednakże zauważyć, że 2020 r. nie podtrzymał tendencji wzrostowej, która została zapoczątkowana w $2018 \mathrm{r}$. Wręcz przeciwnie - odnotowano aż o 17 przypadków zamachów samobójczych mniej niż w 2019 r. Oznaczać to może, że lockdown oraz obowiązek nauki zdalnej nie spowodowały wzrostu liczby prób targnięcia się na swoje życie wśród dzieci w wieku 7-12 lat. Ze względu na sytuację sanitarno-epidemiologiczną i konieczność pracy zdalnej części dorosłego społeczeństwa, w tym rodziców, wydaje się możliwe, że przynajmniej pewien ich odsetek poświęcił swoim dzieciom więcej uwagi oraz czasu, co również (chociaż po części) mogło przełożyć się na spadek analizowanej liczby zamachów samobójczych niezakończonych zgonem. Często bowiem próby samobójcze są właśnie tzw. krzykiem o pomoc, o okazanie zainteresowania przez rodzica. Poświęcenie większej uwagi dziecku, częstsze spędzanie z nim czasu (choćby była to tylko pomoc w lekcjach zdalnych) może ułatwić rodzicowi „wychwycenie" ewentualnych problemów młodego człowieka. Wspólne spędza-

${ }^{14}$ J. Lamm, Samobójstwa wśród młodzieży, https://www.primopsyche.pl/pl/samobojstwa-wsrod-mlodziezy/ [dostęp: 1.09.2021]. 
nie czasu służy zacieśnieniu więzi z rodzicem i bez wątpienia przyczynić się może do tego, że dziecko się otworzy i opowie o dręczących je problemach.

Analiza danych statystycznych KGP odnoszących się do zamachów samobójczych zakończonych zgonem, dokonanych przez dzieci w wieku 7-12 lat, pokazuje, że przypadków tych odnotowano zdecydowanie mniej niż prób, w których do śmierci nie doszło. Najwidoczniejsze różnice zachodzące pomiędzy tymi wartościami należy wskazać w latach 2014-2015 oraz 2017-2020, kiedy to zamachów niezakończonych zgonem było nawet o 42 przypadki więcej niż tych, w których doszło do śmierci dziecka.

Najmniej prób targnięcia się na własne życie zakończonych zgonem dzieci w tej kategorii wiekowej przypadło na lata: 2012, 2017 oraz 2020 (jedynie po 1 przypadku). Najwięcej zgonów na skutek zamachu samobójczego odnotowano w 2015 i 2018 r. - po 5 przypadków rocznie. Od 2018 r. odnotowywana jest tendencja spadkowa w tej kategorii zamachów samobójczych, co stanowi pozytywną wiadomość. Warto zatem zauważyć, że obiektywnie rzecz biorąc, są to niewielkie wartości, co również potwierdzać może wskazane tu wcześniej hipotezy, że próba samobójcza dziecka w większości przypadków nie ma na celu odebrania sobie życia, a zwrócenie uwagi rodzica/opiekuna na potrzeby i problemy młodego człowieka.

Przedstawione dane dotyczące zamachów samobójczych zakończonych zgonem wskazują, że śmierć nastąpiła w skrajnych przypadkach. Być może była ona np. skutkiem nieudzielenia na czas pomocy dziecku czy splotu innych przypadkowych zdarzeń. W statystykach nie wskazano przyczyny zgonu, nie można więc ustalić, czy nastąpił on w wyniku tak dobrze zaplanowanego i przeprowadzonego zamachu samobójczego, czy właśnie choćby dlatego, że nie udzielono dziecku pomocy w odpowiednim czasie (ponieważ np. rodzic tego dnia wrócił z pracy później i kiedy odnalazł dziecko, które zatruło się lekami, było już za późno na uratowanie go).

\section{Dzieci w wieku 13-18 lat}

Ostatnią kategorią wiekową uwzględnioną jako „dzieci” w niniejszym opracowaniu jest przedział 13-18 lat. Wcześniej byli to uczniowie gimnazjum oraz szkół średnich, obecnie uczniowie najstarszych roczników szkoły podstawowej oraz szkół średnich. W tym przedziale wiekowym liczba zamachów samobójczych niezakończonych zgonem była zdecydowanie wyższa niż w kategorii 7-12 lat ${ }^{15}$. Nie ulega wątpliwości, że osoby w tym wieku, będąc jednocześnie w okresie dojrzewania (wręcz u progu dorosłości), rzeczywiście mogą napotykać jeszcze więcej przeszkód i problemów życiowych aniżeli ich młodsi koledzy ${ }^{16}$.

\footnotetext{
15 K. Kuberska-Przekwas, Samobójstwa dzieci..., s. 56.

16 Ibidem, s. 57.
} 
Wskazuje się także na związek między stanem emocjonalnym a zachodzącymi zmianami hormonalnymi („burza hormonalna”) ${ }^{17}$.

Jak zauważa Stanisław Kawula, „grupę podwyższonego ryzyka samobójczego stanowią młodzi dorośli i nastolatki z kryzysem rozwojowym, kryzysem w relacjach międzyludzkich (osamotnienie wewnętrzne, pytania o sens życia), z problemami narkotykowymi (inne uzależnienia), z problemami rodzinnymi, szkolnymi”18. Irena Obuchowska z kolei zwraca uwagę na „szczególnie ważne w okresie rozwoju wpływy środowiskowe. Im dziecko jest starsze, bardziej obserwuje swoje środowisko, niekiedy jest świadkiem, a nieraz także obiektem różnych kulturowych i cywilizacyjnych wynaturzeń, które przenikając do psychiki budują w nim przekonania składające się na "syndrom podłego świata«"19.

Podobnie wypowiedział się również Piotr Gałecki, który stwierdził, że wzrost liczby samobójstw wśród dzieci jest związany z psychicznym funkcjonowaniem dorosłej części społeczeństwa. Według badacza „zdolność radzenia sobie dzieci jest powiązana ze wsparciem psychicznym ze strony rodziców, dorosłych. Niestety brak wsparcia zarówno dla dzieci, jak i dorosłych będących w sytuacji kryzysu psychicznego przyczynia się do takich wzrostów" 20.

Najniższą liczbę zamachów samobójczych niezakończonych zgonem w przedziale wiekowym 13-18 lat odnotowano w 2011 r. (243 przypadki). Od tego też roku do 2015 r. odnotowywano tendencję wzrostową tego zjawiska. Od 2017 r. do 2019 r. ponownie zaobserwowano tendencję wzrostową. W 2019 r. odnotowano najwyższą liczbę zamachów samobójczych - 905 przypadków. Tak jak w poprzedniej kategorii wiekowej, tak też i tutaj w 2020 r. zarejestrowano spadek liczby prób targnięcia się na własne życie niezakończonych zgonem.

Liczba odnotowanych zamachów samobójczych zakończonych śmiercią dzieci w wieku 13-18 lat w Polsce w latach 2010-2020 nie przekroczyła 150 przypadków rocznie. Najwięcej takich sytuacji zarejestrowano w 2013 r. (144 przypadki), najmniej zaś w 2018 r. (92). Co ciekawe jednak, w tej kategorii wiekowej zamachy samobójcze zakończone zgonami w latach 2018-2020 wykazywały tendencję wzrostową. W 2020 r. liczba ta wyniosła 106 przypadków i w porównaniu z 2019 r. wzrosła o 12 zgonów - to niepokojące zjawisko. Oczy-

17 G. Cepuch, A. Kruszecka-Krówka, P. Libe, Wybrane predyktory zachowań suicydentalnych młodzieży w Polsce, „Pielęgniarstwo i Zdrowie Publiczne” 2020, nr 10 (4), s. 292.

18 S. Kawula, Zachowanie samobójcze młodzieży $i$ jej stosunek do kary śmierci, w: Środo-

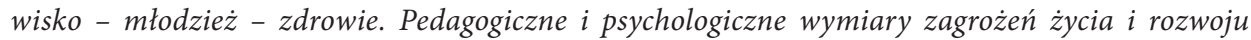
młodzieży, red. J.A. Malinowski, A. Mandecki, Wydawnictwo Edukacyjne „Akapit”, Toruń 2007, cyt. za: M. Makara-Studzińska, Przyczyny prób..., s. 76.

19 I. Obuchowska, Psychologia kliniczna dzieci i młodzieży - wybrane zagadnienia, w: Psychologia kliniczna, red. H. Sęk, PWN, Warszawa 2006, cyt. za: M. Makara-Studzińska, Przyczyny prób..., s. 76.

20 K. Grzelak, W roku pandemii wzrosła liczba samobójstw wśród dzieci. Polska policja pokazuje tragiczne statystyki, https://www.focus.pl/artykul/w-roku-pandemii-wzrosla-liczba-samobojstw-wsrod-dzieci-polska-policja-pokazuje-tragiczne-statystyki [dostęp: 1.09.2021]. 
wiście, nie jest to zapewne wyłącznie efekt sytuacji sanitarno-epidemiologicznej. Jednakże odseparowanie od rówieśników oraz nauka zdalna mogły przyczynić się do zaistnienia lub pogłębienia się już istniejących problemów młodych ludzi ${ }^{21}$, którzy siłą rzeczy, spędzając jeszcze więcej czasu w świecie wirtualnym, mogli mieć styczność np. z treściami dotyczącymi sposobów popełniania samobójstwa $^{22}$. Jest to szczególnie niebezpieczne zwłaszcza dla osób, które kwestionują sens swojego istnienia, np. na skutek przytłaczających je problemów.

Z kolei takie czynniki, jak brak specjalistycznej pomocy czy wsparcia ze strony rodziny, również mogły przełożyć się na podjęcie decyzji o zakończeniu życia ${ }^{23}$. Jak wskazują Aleksandra Bąbik oraz Dominik Olejniczak, rodzina ma największy wpływ na zapobieganie samobójstwom ${ }^{24}$. Dlatego też, zwłaszcza w obecnych czasach, kiedy młodzi ludzie mają utrudniony bezpośredni kontakt ze znajomymi, przyjaciółmi, ważne jest dla nich wsparcie ze strony bliskich. Wiek młodzieńczy należy zatem uznać za okres, w którym istnieje znaczne ryzyko podjęcia zamachu samobójczego ${ }^{25}$.

Wydaje się, że spory odsetek rodziców/opiekunów dzieci z tej grupy wiekowej wychodzi z założenia, że nie potrzebują one aż tak wiele uwagi i pomocy ze strony dorosłych. Są przecież znawcami i aktywnymi użytkownikami nowych technologii, więc nie trzeba im pomagać np. w technicznych aspektach związanych $\mathrm{z}$ nauką (w tym w czasie nauki zdalnej).

Warto jednak wziąć pod uwagę wielokrotnie już podkreślany fakt, że wraz $\mathrm{z}$ wiekiem dziecku przybywa problemów. Wynikają one ze wzrostu stopnia trudności nauki, z procesu dorastania (zmiany fizyczne i psychiczne), przeżywania pierwszych miłości (w tym i tych odrzuconych), relacji z rówieśnikami, rodzicami (które w okresie „młodzieńczego buntu” mogą być dosyć burzliwe). Nie jest zatem żadnym zaskoczeniem, że wraz z wiekiem i ze zwiększającą się liczbą możliwych trudności (ewentualnych przyczyn samobójstwa), jakie dziecko spotyka na swojej drodze, wzrasta również liczba zamachów samobójczych odnotowywanych w statystykach policyjnych.

\section{Zamachy samobójcze dzieci z uwzględnieniem powodu ich popełniania - tzw. problemy szkolne}

Pomimo chęci szerszego wskazania przyczyn zamachów samobójczych wśród dzieci dokonanie tego na podstawie policyjnej statystyki jest niestety

21 Ibidem.

22 M. Rzadkowska, Zachowania samobójcze..., s. 166.

23 J. Szymańska, Zapobieganie samobójstwom dzieci i młodzieży. Poradnik dla pracowników szkół i placówek oświatowych oraz rodziców, Ośrodek Rozwoju Edukacji, Warszawa 2016, s. 15-16.

24 A. Bąbik, D. Olejniczak, Uwarunkowania i profilaktyka..., s. 113.

25 K. Kuberska-Przekwas, Samobójstwa dzieci..., s. 57. 
niemożliwe $\mathrm{z}$ uwagi na podnoszony już brak wyodrębnienia przedziałów wiekowych w danych dotyczących poszczególnych przyczyn samobójstw w Polsce. Na podstawie analizy wymienionych tam powodów można wskazać tylko jeden, który stricte odnosiłby się do zamachów samobójczych wśród dzieci. Co ciekawe, od 2017 r. dane odnośnie do i tej przyczyny stały się trudne w interpretacji. Powód tej trudności zostanie przedstawiony dalej.

Liczbę zamachów samobójczych dzieci w Polsce w latach 2010-2020 w kategorii „powód: problemy szkolne” przedstawiono w tabeli 3.

TABela 3. Liczba zamachów samobójczych dzieci w Polsce w latach 2010-2020 w kategorii "powód: problemy szkolne”

\begin{tabular}{|c|c|c|}
\hline \multirow{2}{*}{ Rok } & \multicolumn{2}{|c|}{ Powód: problemy szkolne } \\
\hline & bez zgonu & zgon \\
\hline 2010 & 30 & 11 \\
\hline 2011 & 24 & 7 \\
\hline 2012 & 34 & 14 \\
\hline 2013 & 27 & 12 \\
\hline 2014 & 41 & 13 \\
\hline 2015 & 53 & 13 \\
\hline 2016 & 59 & 12 \\
\hline 2017 & $\begin{array}{c}149 \\
\text { (problemy w szkole lub pracy) }\end{array}$ & $\begin{array}{c}41 \\
\text { (problemy w szkole lub pracy) }\end{array}$ \\
\hline 2018 & $\begin{array}{c}160 \\
\text { (problemy w szkole lub pracy) }\end{array}$ & $\begin{array}{c}38 \\
\text { (problemy w szkole lub pracy) }\end{array}$ \\
\hline 2019 & $\begin{array}{c}175 \\
\text { (problemy w szkole lub pracy) }\end{array}$ & $\begin{array}{c}29 \\
\text { (problemy w szkole lub pracy) }\end{array}$ \\
\hline 2020 & $\begin{array}{c}159 \\
\text { (problemy w szkole lub pracy) }\end{array}$ & $\begin{array}{c}35 \\
\text { (problemy w szkole lub pracy) }\end{array}$ \\
\hline
\end{tabular}

Źródło: Opracowanie własne na podstawie danych statystycznych KGP.

W pierwszej kolejności należy zauważyć, że od 2017 r. w policyjnych danych statystycznych w tej samej kategorii zaczęto ujmować także problemy w pracy. Od tego roku kategorię tę opisywano jako „problemy w szkole lub pracy”. Do 2017 r. problemy w szkole były ujmowane oddzielnie. Z pracą z kolei związane były takie kategorie, jak np. złe warunki ekonomiczne czy nagła utrata źródła utrzymania. Nie będą to jednakże dane poddawane analizie z uwagi na fakt, że dzieci, co do zasady, nie podejmują pracy zarobkowej.

Połączenie tych kategorii bez wyodrębnienia choćby grup wiekowych nie pozwala ustalić, w ilu przypadkach zamach samobójczy popełniło dziecko, a w ilu dorosły. Brak jest też na stronie internetowej (gdzie znajdują się dane 
statystyczne) jakiegokolwiek wyjaśnienia, dlaczego informacje te są przedstawiane łącznie. Sama zmiana sposobu prowadzenia statystyk czy formularza, na którym odnotowuje się przypadki samobójstw, nie wyjaśnia zbyt wiele. Warto także zauważyć, że wzory formularzy nie są udostępniane, więc samo wskazanie, że zmieniła się ich nazwa i sposób klasyfikowania danych (patrz fragment niniejszej publikacji o źródłach danych), nie rozjaśnia tej kwestii zbytnio, jeżeli analizujący dane statystyczne nie może porównać pytań zawartych w tych formularzach celem ustalenia, jakie oraz w jakim stopniu zmiany tutaj zaszły.

Oczywiste jest, że im więcej kategorii danych, tym ich interpretacja, przedstawianie czy klasyfikacja mogą być utrudnione. Może to też powodować mniejszą przejrzystość tych informacji. Jednakże wydaje się, że pomiędzy problemami $\mathrm{w}$ szkole a problemami $\mathrm{w}$ pracy istnieje zasadnicza różnica, inne są bowiem miejsce i wiek osób, których dotyczą owe kwestie. Dlatego właśnie rozróżnienie to było jak najbardziej klarowne.

W latach 2010-2016 najmniej niezakończonych zgonem zamachów samobójczych z powodu problemów w szkole odnotowano w 2011 r. - 24. Najwięcej zarejestrowano w 2016 r. - 59 przypadków. W latach 2017-2020 liczba prób samobójczych $\mathrm{z}$ powodu problemów w szkole lub pracy znacznie wzrosła - do ponad 140 przypadków rocznie. Niestety ze względu na połączenie tych danych trudno wskazać, jaka była tendencja zamachów samobójczych popełnianych z powodu problemów w szkole w ostatnich latach, w tym w $2020 \mathrm{r}$.

Próby samobójcze zakończone zgonem również i w tej kategorii wiekowej wykazywały wartości niższe. Najmniej odnotowano ich w 2011 r. - 7 przypadków, najwięcej w 2012 r. - 14. W latach 2014-2016 liczba ta utrzymywała się na niemal stałym poziomie 12-13 zamachów samobójczych zakończonych śmiercią rocznie. W latach 2017-2020 trudno jednoznacznie wskazać, ile dzieci odebrało sobie życie z powodu problemów szkolnych, ponieważ - jak już wcześniej wskazano - wartości z tej kategorii zsumowano z przypadkami samobójstw wynikających z problemów w pracy.

\section{Zamachy samobójcze dzieci z uwzględnieniem kategorii "Informacja o pracy lub nauce - uczeń"}

Jako ostatnie analizie zostały poddane dane statystyczne dotyczące liczby zamachów samobójczych dzieci w kategorii „Informacja o pracy lub nauce uczeń". Przedstawione one zostały w tabeli 4.

$\mathrm{Na}$ podstawie danych zawartych $\mathrm{w}$ tej tabeli można ustalić, ile osób dokonujących zamachów samobójczych zostało zakwalifikowanych w policyjnej statystyce jako uczniowie. Co ciekawe, jeśli dokonać zsumowania liczby osób 
z kategorii wiekowych ujętych w tabeli 2 (7-12 lat oraz 13-18 lat), wartości te nie pokrywają się $\mathrm{z}$ danymi $\mathrm{z}$ tabeli 3 .

Tabela 4. Liczba zamachów samobójczych dzieci w Polsce w latach 2010-2020 w kategorii „Informacja o pracy lub nauce - uczeń”

\begin{tabular}{|c|c|c|}
\hline \multirow{2}{*}{ Rok } & \multicolumn{2}{|c|}{ Informacja o pracy lub nauce - uczeń } \\
\cline { 2 - 3 } & bez zgonu & ze zgonem \\
\hline 2010 & 269 & 122 \\
\hline 2011 & 226 & 102 \\
\hline 2012 & 262 & 123 \\
\hline 2013 & 347 & 166 \\
\hline 2014 & 472 & 158 \\
\hline 2015 & 465 & 132 \\
\hline 2016 & 454 & 107 \\
\hline 2017 & 689 & 119 \\
\hline 2018 & 735 & 102 \\
\hline 2019 & 877 & 93 \\
\hline 2020 & 780 & 113 \\
\hline
\end{tabular}

Źródło: Opracowanie własne na podstawie danych statystycznych KGP.

Definicja pojęcia „uczeń” nie została wskazana w miejscu zamieszczenia danych. Wydaje się jednak, że mowa tu po prostu o osobach, które uczą się (lub uczyły się) w szkołach podstawowych, gimnazjach oraz szkołach średnich. Pojawia się zatem pytanie, jaki jest powód tejże rozbieżności. Być może nie wszystkie osoby ujmowane w analizowanych wcześniej przedziałach wiekowych (pomimo obowiązku nauki do 18 r.ż.) taką naukę odbywały i dlatego nie zostały one zakwalifikowane jako „uczniowie”. Różnica między sumą odnotowanych osób, które popełniły zamachy samobójcze, mając 7-18 lat, a danymi zamieszczonymi w tabeli 4 wskazuje, że to właśnie pierwsza kategoria danych była wyższa niż liczba odnotowanych osób o statusie ucznia.

Jak wskazują A. Bąbik oraz D. Olejniczak, istnieją również rozbieżności $\mathrm{w}$ danych dotyczących zamachów samobójczych $\mathrm{w}$ statystykach przedstawianych przez KGP oraz przez Główny Urząd Statystyczny (GUS). Autorzy ci ową różnicę wyjaśniają faktem, że „GUS korzysta z informacji z kart zgonu przekazywanych do urzędów statystycznych przez szpitale i zakłady pogrzebowe po przeprowadzeniu sekcji zwłok, a Policja głównie z informacji uzyskanych po oględzinach miejsca zdarzenia, jeszcze przed sekcją zwłok i wystawieniem karty zgonu"26.

${ }^{26}$ A. Bąbik, D. Olejniczak, Uwarunkowania i profilaktyka..., s. 103. 
Wracając jednak do analizy danych statystycznych KGP, należy wskazać, że najmniejszą liczbę osób o statusie ucznia, które dokonały zamachu samobójczego niezakończonego zgonem, odnotowano w 2011 r. - 226 osób. Z kolei najwyższą liczbę w tej kategorii zarejestrowano w 2019 r. - 877 osób. W ciągu ostatniej dekady, pomimo niejednolitej tendencji, można zauważyć, że liczba uczniów, którzy dokonali próby samobójczej, wzrosła z poziomu ponad 200 osób do niemal 900. Jest to znaczny wzrost. Warto jednakże zasygnalizować, że i w tej kategorii danych w 2020 r. nie odnotowano wzrostu liczby osób o statusie ucznia, które dokonały zamachu samobójczego. Wręcz przeciwnie - liczba ta spadła o niemal 100 osób w porównaniu z 2019 r.

Liczba prób samobójczych zakończonych zgonem dokonanych przez osoby zakwalifikowane w danych KGP jako „uczeń” również była niższa od liczby zamachów samobójczych, w wyniku których nie doszło do śmierci. Najwięcej zgonów odnotowano w tej kategorii w 2013 r. (166 przypadków), najmniej zaś w 2019 r., kiedy liczba ta spadła poniżej 100.

Należy jednak zauważyć, że od 2019 r. liczba zamachów samobójczych zakończonych zgonem wśród uczniów wykazuje tendencję wzrostową. Jest to niepokojąca informacja - w 2020 r. liczba ta wzrosła aż o 20 przypadków (w porównaniu z 2019 r.). Fakt ten, w połączeniu ze wskazanym wcześniej wzrostem liczby zamachów samobójczych zakończonych zgonem, dokonanych przez dzieci w wieku 13-18 lat, może prowadzić do wniosku, że rzeczywiście w 2020 r. lockdown mógł nasilić zjawisko samobójstw (zakończonych zgonem) wśród starszej młodzieży.

\section{Podsumowanie}

Zamachy samobójcze godzą w najważniejsze dobra, jakie posiada dziecko jego życie lub zdrowie. Próby samobójcze dzieci stanowią znaczny odsetek wszystkich tego typu czynów dokonywanych w Polsce w latach 2010-2020, a ich liczba wzrasta wraz $z$ wiekiem osób dokonujących zamachu na własne życie. Z analizy danych KGP wynika, że liczba odnotowanych zamachów samobójczych zakończonych zgonem była niższa aniżeli liczba prób, w których do śmierci nie doszło.

Pozytywną informacją jest brak jakichkolwiek odnotowanych przypadków zamachów samobójczych wśród dzieci w wieku 0-6 lat. Najwięcej prób odebrania sobie życia (zarówno ze zgonem, jak i bez) zarejestrowano wśród dzieci w wieku 13-18 lat. Oznacza to, że młodzież w tej grupie wiekowej jest najbardziej narażona na analizowane zjawisko, chociażby z uwagi na mnogość problemów wynikających z etapu dojrzewania czy też wiążących się z bardziej świadomym pojmowaniem pewnych kwestii. Niepokoi fakt, że w tej kategorii wiekowej odnotowano w 2020 r. wzrost liczby zamachów samobójczych za- 
kończonych zgonem. W kategorii 7-12 lat liczba ta w czasie lockdownu spadła zarówno w przypadku prób zakończonych, jak i niezakończonych zgonem.

Pomimo wielu kategorii danych zawartych w policyjnych statystykach nie jest łatwo określić dynamikę zamachów samobójczych dzieci w Polsce w latach 2010-2020. O ile analiza liczby prób odebrania sobie życia w poszczególnych przedziałach wiekowych nie nastręcza trudności, o tyle nie może to być jedyna kategoria danych, na której miałyby być oparte rozważania naukowe. Niestety, pośród informacji dotyczących powodów dokonywania zamachów samobójczych brak jest wyszczególnienia, które z nich odnoszą się stricte do dzieci. Oczywiście, można domniemywać, że przykładowo problemy w pracy czy utrata źródła zarobku rzeczywiście ich nie dotyczą.

Kategoria powodu zamachu samobójczego określana jako „problemy w szkole" na pewno do dzieci się odnosi. Z perspektywy osoby dorosłej wydawać się może, że w życiu człowieka pojawia się o wiele więcej bardziej istotnych problemów, jak np. choroby, utrata bliskiej osoby. Jednakże analizując dane z tej kategorii statystyk, należy mieć na uwadze, że dla dziecka w wieku 7-18 lat to m.in. szkoła oraz relacje $\mathrm{z}$ rówieśnikami stanowią centrum zainteresowań. Toteż z perspektywy młodego człowieka wszelkie problemy na tym polu - jeżeli zaczynają się nawarstwiać lub powiększać - mogą stanowić powód do targnięcia się na własne życie, zwłaszcza w sytuacji braku wsparcia np. ze strony bliskich dziecku osób. Problemy w szkole nie mogą być jednakże traktowane jako jedyny powód popełniania samobójstw przez dzieci. Dlatego też trafnym postulatem jest stwierdzenie, że przy danych statystycznych dotyczących powodów zamachów samobójczych należałoby wprowadzić rozgraniczenie na przypadki, w których próby takiej dokonało dziecko, a w których osoba dorosła. Interesujące $\mathrm{z}$ naukowego punktu widzenia byłoby także podzielenie danych, uwzględniając płeć osób dokonujących zamachów samobójczych.

Niedostatki statystyk policyjnych nie są skutkiem błędnego ich prowadzenia. Po prostu samobójstwo nie jest zdarzeniem takim jak przestępstwo, co do którego prowadzi się szczegółowe postępowanie wyjaśniające jego przyczyny i przebieg. Jak wskazano, również statystyki GUS nie zawierają wszystkich przypadków samobójstw w Polsce. Sam problem jednak - tj. zamachów samobójczych, w tym szczególnie tych wśród dzieci - powinien być analizowany nie tylko na gruncie naukowym (np. przez suicydologię, kryminologię czy socjologię), ale przede wszystkim na etapie przeciwdziałania (np. pomoc psychologiczna w szkołach, telefony zaufania itd.). Na szali bowiem znajduje się najważniejsze dobro, jakie posiada człowiek. Sytuacja jest tym poważniejsza, że mowa tu o dzieciach. Zamach samobójczy może w skrajnym przypadku pozbawić jednostkę życia lub też często skutkować trwałym kalectwem. 


\section{Bibliografia}

Bąbik A., Olejniczak D., Uwarunkowania i profilaktyka samobójstw wśród dzieci i młodzieży w Polsce, „Dziecko Krzywdzone. Teoria, badania, praktyka” 2014, vol. 13, no. 2, s. 99-121.

Cepuch G., Kruszecka-Krówka A., Libe P., Wybrane predyktory zachowań suicydentalnych młodzieży w Polsce, „Pielęgniarstwo i Zdrowie Publiczne” 2020, nr 10 (4), s. 291-296.

Drzewiecki P., Samobójstwa nastolatków w Internecie w perspektywie pedagogiki mediów, „Kultura - Media - Teologia” 2011, nr 2, s. 61-73.

Grzelak K., W roku pandemii wzrosła liczba samobójstw wśród dzieci. Polska policja pokazuje tragiczne statystyki, https://www.focus.pl/artykul/w-roku-pandemii-wzrosla-liczba-samobojstw-wsrod-dzieci-polska-policja-pokazuje-tragiczne-statystyki [dostęp: 1.09.2021].

Hołyst B., Suicydologia, LexisNexis, Warszawa 2012.

https://statystyka.policja.pl/st/wybrane-statystyki/zamachy-samobojcze [dostęp: 11.05.2021].

https://statystyka.policja.pl/st/wybrane-statystyki/zamachy-samobojcze/122325,Zamachy-samobojcze-od-1999-do-2012.html [dostęp: 11.05.2021].

https://statystyka.policja.pl/st/wybrane-statystyki/zamachy-samobojcze/122324,Zamachy-samobojcze-od-2013-do-2016.html [dostęp: 11.05.2021].

https://statystyka.policja.pl/st/wybrane-statystyki/zamachy-samobojcze/63803,Zamachy-samobojcze-od-2017-roku.html [dostęp: 11.05.2021].

Kawula S., Zachowanie samobójcze młodzieży i jej stosunek do kary śmierci, w: Środowisko - młodzież - zdrowie. Pedagogiczne i psychologiczne wymiary zagrożeń życia i rozwoju młodzieży, red. J.A. Malinowski, A. Mandecki, Wydawnictwo Edukacyjne „Akapit”, Toruń 2007, s. 105-127.

Kuberska-Przekwas K., Samobójstwa dzieci i młodzieży jako choroba społeczna, „Warmińsko-Mazurski Kwartalnik Naukowy, Nauki Społeczne” 2014, nr 1, s. 51-70.

Lamm J., Samobójstwa wśród młodzieży, https://www.primopsyche.pl/pl/samobojstwa-wsrod-mlodziezy/ [dostęp: 1.09.2021].

Makara-Studzińska M., Przyczyny prób samobójczych u młodzieży w wieku 14-18 lat, „Psychiatria” 2013, t. 10, nr 2, s. 76-83.

Obuchowska I., Psychologia kliniczna dzieci i młodzieży - wybrane zagadnienia, w: Psychologia kliniczna, red. H. Sęk, PWN, Warszawa 2006, s. 25-46.

Rzadkowska M., Zachowania samobójcze wśród dzieci i młodzieży - charakterystyka ryzyka i profilaktyka, „Studia Prawnicze. Rozprawy i Materiały” 2016, nr 1 (18), s. $161-179$.

Rząsa D., Samobójstwa nastolatków - dlaczego oficjalne statystyki pokazuja tylko część prawdy, https://sledztwopisma.pl/sledztwo-w-liczbach/samobojstwa-nastolatkowdlaczego-oficjalne-statystyki-pokazuja-tylko-czesc-prawdy/ [dostęp: 1.09.2021].

Szymańska J., Zapobieganie samobójstwom dzieci i młodzieży. Poradnik dla pracowników szkół i placówek oświatowych oraz rodziców, Ośrodek Rozwoju Edukacji, Warszawa 2016. 
mgr JUSTYNA OMELJANIUK

e-mail: justyna1994onet.pl@onet.pl

Od 2013 r. doktorantka w Katedrze Prawa Karnego i Kryminologii na Wydziale Prawa Uniwersytetu w Białymstoku. Absolwentka studiów podyplomowych mediatorów sądowych na Uniwersytecie w Białymstoku. Aktywnie zaangażowana w działalność Studenckiego Koła Nauk Penalnych. Interesuje się prawem karnym, kryminologicznymi aspektami przestępczości samochodowej i kryminalistyką.

Since 2013, a doctoral student at the Department of Criminal Law and Criminology at the Faculty of Law of the University of Białystok. A graduate of postgraduate studies in court mediators at the University of Białystok. Actively involved in the activities of the Students' Circle of Penal Sciences. She is interested in criminal law, criminological aspects of car crime and forensics. 